\title{
Filial Descent: The African Roots of Postcolonial Literature in Italy
}

Cristina Lombardi-Diop

Loyola University Chicago, clombardidiop@luc.edu

Follow this and additional works at: https://ecommons.luc.edu/modernlang_facpubs

Part of the Modern Languages Commons, and the Modern Literature Commons

\section{Author Manuscript}

This is a pre-publication author manuscript of the final, published article.

\section{Recommended Citation}

Lombardi-Diop, Cristina. Filial Descent: The African Roots of Postcolonial Literature in Italy. Forum for Modern Language Studies, 56, 1: 66-77, 2020. Retrieved from Loyola eCommons, Modern Languages and Literatures: Faculty Publications and Other Works, http://dx.doi.org/10.1093/fmls/cqz058

This Article is brought to you for free and open access by the Faculty Publications and Other Works by Department at Loyola eCommons. It has been accepted for inclusion in Modern Languages and Literatures: Faculty Publications and Other Works by an authorized administrator of Loyola eCommons. For more information, please contactecommons@luc.edu. c) () $\odot$

This work is licensed under a Creative Commons Attribution-Noncommercial-No Derivative Works 3.0 License. (c) Lombardi-Diop, 2020. 
Filial Descent: The African Roots of Postcolonial Literature in Italy.

Cristina Lombardi-Diop, Loyola University Chicago

Author's accepted manuscript.

\begin{abstract}
The essay concentrates on two seminal postcolonial novels by authors of African descent: Cristina Ubax Ali Farah's Madre piccola (2007) (Little Mother: A Novel) and Gabriella Ghermandi's Regina di fiori e di perle (2007) (Queen of Flowers and Pearls). It argues that these works give expression to an African diasporic urban generation that is changing the literary legacy of the Horn of Africa. The co-presence of multiple genres, with orality appearing as a strong influence on their written narrative forms, places these novels within the larger formation of a black African literary tradition. By looking at these two novels from an Africanist perspective, the essay takes into consideration their plurilingual interventions, the use of glossaries and language calques, alongside the presence of Somali and Amharic cultural references. The author highlights the authorial perspective as a 'filial descent' that addresses the complexity of a postcolonial generational shift in contemporary African literature. By placing these works within an African literary tradition and showing their critical de-centering of such tradition, the essay reconfigures a possible space of cultural autonomy for African postcolonial writing away from the Italocentric space of discourse that has so far dominated its critical reception in Italy.
\end{abstract}

Keywords: Postcolonial literature in Italy, African sources, Somali, Amharic, generational shift.

Postcolonial literature in Italy has emerged as a polylingual and transnational corpus, often accompanied by bilingual editions, plurilingual texts, glossaries, and acts of self-translation. This polyphony is due to the fact that, since its inception, postcolonial writing had to deal with the essentially monolingual and monocultural nature of the Italian readership and the editorial market, to the point where its initial reception as 'immigrant literature' has rendered invisible its marked cultural roots. In this chapter, I will concentrate on two seminal postcolonial novels by authors of African descent: Gabriella Ghermandi, Ethiopian Italian writer, story-teller, and performance artist, author of Regina di fiori e di perle (2007), (Queen of Flowers and Pearls) and poet and novelist Cristina Ubax Ali Farah, Somali Italian, author of Madre piccola (2007) (Little Mother: A Novel) and Il comandante del fiume (2014). 
${ }^{1}$ For both, Italian is the mother tongue learned through the filial relationship with a parent-her father, in the case of Ghermandi, and her mother, in the case of Ali Farah. Ali Farah's creative and engaged social activities all center on the role of language and storytelling in exile. Ghermandi has embraced the creative potential inherit in the complex relationship between orature, performance, and music by complementing her writing activity with oral and musical performances and the creation of The Atse Tewodros Project, a musical ensemble including Ethiopian and Italian musicians, mixing jazz and traditional Ethiopian music. ${ }^{2}$ For both Ghermandi and Ali Farah, the private and familiar intimacy with the Italian language conditions their choice of it as a written language. Yet, for both, writing prose fiction in Italian does not solely affect the possibility of accessing the Italian literary tradition and Italy's publishing market. It also impacts, as I suggest here, the literary and cultural forms of their countries of origin. This is because the questione della lingua is not only a quintessentially Italian dispute. Historically originating in the tension between the codified prescriptions of written and oral forms, the language question is profoundly embedded within the birth of an African literary tradition, tied as it is to the cultural history of colonial and postcolonial Africa.

The co-presence of multiple genres, with orality appearing as a strong influence on their narrative forms, places Madre piccola and Regina di fiori e di perle within the larger formation of a black African literary expression. ${ }^{3}$ By drawing on the complexity of the narration of the African experience as a whole, both Ghermandi's and Ali Farah's works partake of a larger African corpus, 'intensively engaged with politics and history' and with a desire 'to contribute to the construction of viable postcolonial cultural identities for the new African nations' after decolonization. ${ }^{4}$ However, these diasporic novels also underscore a changed literary scenario. They, in fact, so cogently represent what is now the expression of a younger and diasporic urban generation that is changing 
the literary legacy of the Horn of Africa. By placing these works within an African literary tradition and showing their critical de-centering of such tradition, I am interested in reconfiguring - for African postcolonial writing - a possible space of cultural autonomy away from the Italocentric space of discourse that has so far dominated its critical reception in Italy.

The diasporic, hybrid nature of postcolonial literature has been at the center of critical attention in the peninsula. Critics have highlighted the cultural hybridity and polylingual nature of Madre piccola and Regina di fiori e di perle. Alessandra Di Maio defines Ali Farah's transformation of Italian and her use of Somali and English in Madre piccola as a form of 'transnational, all- inclusive idiom', 'a crucial site of identity for identity exploration'. ${ }^{5}$ In turn, Loredana Polezzi has argued that 'for Ghermandi and Ali Farah, Italian is the language of the mother (or the father), rather than an adopted language, yet their mixed heritage means that this is also an idiom inhabited by other presences, other voices, other traditions, and their writing is distinctly polyphonic in texture as well as in structure'. Polezzi moves beyond the mere definition of Ghermandi and Ali Farah as migrant writers because of their personal biographies, 'inscribed with mobility and multiple cultures', and their personal relationship with the Italian language that 'cannot be identified with the experience of migration'. ${ }^{6}$ Similarly, Lucia Quaquarelli highlights the limitation of the label 'migrant literature' and the 'rhetorics of innovation' that has often forced postcolonial literature to serve a social and educational purpose, functional to promoting intercultural mediation. ${ }^{7}$ As a result, postcolonial writing has taken an 'ancillary (subaltern) and utilitarian function' that has tended to overlook the 'opacity' of the use of languages unfamiliar to an Italian readership. ${ }^{8}$ On the opposite spectrum, Polezzi believes that 'Italy's ambitious position in center-periphery models of world cultures" ${ }^{9}$ makes postcolonial texts 'eminently "Italian" although (or, perhaps, precisely because) they are also transnational'. ${ }^{10} \mathrm{My}$ analysis moves in a different direction. By 
looking at these two novels from an Africanist perspective, I take into consideration the plurilingual interventions alongside the presence of Somali and Amharic cultural references. I argue that Madre piccola and Regina di fiore e di perle are - linguistically and culturally - eminently Somali and Ethiopian (respectively), yet are written from the perspective of a diasporic, filial descent that addresses the complexity of a postcolonial generational shift in contemporary African literature.

The editorial industry has recognized the 'opacity' of postcolonial writing for the Italian readers and made recourse to editorial strategies, such as footnotes and glossaries, to mitigate the unfamiliar presence of foreign 'minor' lexicon. ${ }^{11}$ In African literature more generally, paratextual material - such as footnotes and glossaries - have often functioned as 'sub-texts', serving 'the pedagogical scope of foregrounding the distance between European and African sociocultural reality' and highlighting the non-commensurability of some cultural-bond concepts. ${ }^{12}$ In Madre piccola and Regina di fiori e di perle, Somali and Amharic terms and cultural concepts appear in Italian translation in a separate glossary at the beginning and end of the book, respectively. In Madre piccola, the glossary lists Somali greetings, Arabic-Muslim invocations, and Somali calques that retrace a specific colonial genealogy, 'words with Italian origins that entered the Somali language during the colonial domination'. ${ }^{13}$ Examples such as kabushiini (from capuccino), fasoleeti (from fazzoletto), draddorio (from trattoria) are words of everyday use that attest to the decades of Italian colonial presence in Somalia. One such term is ciyaal mission (the children of the missions) used to indicate the children abandoned by their Italian fathers following a 1937 Royal Decree that prohibited interracial unions between Italian citizens and colonial subjects, children who were raised in Catholic missionary schools. Ali Farah's use of Somali calques of Italian words is not a neutral strategy. It reveals the proximity of the two languages in a colonial genealogy embedded within the material and affective life of its users, while also providing 'evidence of the 
creative manipulation of the Italian language by the colonized'. ${ }^{14}$ In the case of Regina di fiori e di perle, the glossary explains not only food terminology and words of every-day usage, but also the meaning of culturally "thick" concepts such as proper nouns, festivities in the Ethiopian calendar - the Meskel (the Feast of the Holy Cross), the Meskerem (the New Year) - and one of the key poetic forms present in the novel, the qene. The glossary, appearing in the Italian and English versions, underscores the intended readership as predominantly Europhone.

In the Italian version of Regina di fiori e di perle, Ghermandi goes a step farther, embedding within her novel not only calques but a poetic song transcribed in Amharic. The Amharic ostentatiously differs from the Latin alphabet, effecting a dizzying de-familiarization for the Italian reader. The visible presence of the Amharic literary tradition is one of the 'pearls' of the novel's title, with the many descriptions of Addis Ababa being one its 'flower' (the literal meaning in Amharic of the city's name is, indeed, 'new flower'). ${ }^{15}$ In this case, the pearl is a poetic song following the metric structure of the millenarian epic poetic form known as g't'm. The poem is in praise of the guerilla hero Yacob, whose heroic resistance against the Italians at the time of the invasion occupies the initial part of the novel. It was composed in Amharic by Ethiopian poet Iasu Gorfu and was originally seven-pages long, as it narrated the whole novel in poetic verses. Ghermandi selected only the stanzas she deemed functional to her story and translated them from Amharic into Italian. ${ }^{16}$ By offering a song whose material inscription is intelligible only to Amharic readers, Ghermandi operates a disturbance within the translingual and trancultural interaction with the Italian readers implicit in the use of a glossary. ${ }^{17}$ The presence of the Amharic alphabet functions as a cultural and visual strategy that reveals the author's intended goal to reach an Ethiopian 
readership. By excluding (even if only for brief portions of the text) Italophone readers, this particular editorial choice implicitly shifts the focus from an Italian language question to one that is specific to the African language context.

The peculiarity of language policies in colonial East Africa impacts these two writers differently. From the perspective of the Horn of Africa, the hegemony of certain local languages at the expense of others has led to serious sociopolitical inequalities among ethnic groups. ${ }^{18}$ With English as the de facto second official language, Ethiopia is unique in not having a dominant colonial linguistic legacy. One of the most linguistically diversified countries of the world, Ethiopia adopted Amharic as her official language only in 1955, even if written Amharic literature has a millenarian tradition. Since then, buttressed by legislation, the Amhara linguistic hegemony functioned alternatively as a political tool to discourage the use of local languages or to reward rebellious ethnic groups. Ethno-linguistic identity, rather than solely religion, has been a source of powerful affiliation. Eritrea is another case in point. Before its annexation by Ethiopia in 1962, the official languages of Eritrea were Tigrignya and Arabic. The elimination of these languages from most public roles by the Ethiopian Derg was one of the most contentious elements in the escalation of Eritrea's struggle for separation from Ethiopia. ${ }^{19}$ Exiled Ethiopians and Eritreans are nonetheless increasingly critical of the divisive cultural policies of their respective countries. As Ethiopian poet Solomon Deressa (who writes both in Amharic and English) puts it, 'The real questions is: can we continue to speak of Ethiopian Poetry? [...] Is it time to be thinking rather of poetries from the Horn of Africa?'. ${ }^{20}$

Somalia, rather differently, it is uniquely positioned in the region by being a predominantly monolingual state. The transcription of the Somali language into the Latin alphabet by the regime of Siyad Barre made the transition from oral expression to Somali written culture rather 
complicated. The oral tradition of a highly formalized poetry, now transcribed in written form, continues to be at the center of the Somali's literary canon and national life. Poets are highly praised national figures and poetic expression often hides a political discourse. As a highly codified, male poetic form, the poetic oral genre embodies the canon of national poetry. ${ }^{21}$ The hegemonic position of oral poetry in relation to other - less codified and marginalized- genres, such as oral narratives told by women, has much to do with ambivalent attitudes towards writing. While written poetry highlights the forced entry into modernity brought by the Italians and the British, the majority of Somali still understands oral poetry as 'the sweet mother tongue' that refers nostalgically to a world forever lost. ${ }^{22}$ Despite the dominance of Somali poetry, its oral metaphorsderived from the pastoral and nomadic environment - do not make much sense for the young urbanized, less so for the Somali expatriates in Italy, Canada, or the United States. There is a felt need for a new written language of expression for contemporary literature. The nostalgia for orality in nationally acclaimed Somali poetry increases the gap between the older and the younger generation in exile, as the later grows progressively alienated from its oral poetic tradition and its cultural roots. The use of Italian among the Somali elites, including Ali Farah's father, widens this gap from old and new generations, since 'in today's Somalia, [...] Italian remains only as the old colonial language spoken by a dying generation, and is largely ignored by young people'. ${ }^{23}$

Ghermandi's and Ali Farah's novels inscribe the need for a generational passage and a gender shift both at thematic and stylistic level. Their highly crafted texts embody the expression of a new generation of female diasporic writing where women feature predominantly as the narrative voices and catalysts of the events. In Ghermandi's Regina di perle e di fiori, the main narrative frame belongs to Mahlet's voice, a young girl who listens and then gathers the stories of five 
characters, women and men, about theirs and Ethiopia's past. The novel spans over Italy's 1935 colonial aggression, the resistance war against the Italians, the Menghistu regime of the 1970s and 1980s, and up to contemporary times. At the end of an elaborate process of oral narration and remembrance, which coincides with the very end of the book, Mahlet sets herself to the task of transcribing the stories into writing. 'As a grown-up woman, you will be our storyteller,' ${ }^{24}$ the household's venerable elders always said to Mahlet; 'hold on tight to that curiosity of yours and collect all the stories you can. One day you'll be our narrating voice. You will cross the same sea that Peter and Paul crossed, and you will take our stories to the land of the Italians. You will be the voice of our history, a history that cannot be forgotten'. ${ }^{25}$ The intergenerational passage of historical memory lends the novel its structural form. Faithful to the elders' mandate, Ghermandi acted as a 'narrating voice', crafting her narrative by collecting the remarkable stories of the people she met during her many travels back to Addis Ababa. This diasporic condition allows the coming into being of this postcolonial novel. Similarly, Mahlet is a gatherer of memories, refusing the authorial role: 'I am only the one who collected the stories,' she affirms at the end of the novel. ${ }^{26}$ The genealogy of diasporic filial descent, in this case, works as a transcultural and transhistorical passage serving a political purpose.

Ghermandi's multiple oral sources in Regina di fiori e di perle refer back, albeit unintentionally, ${ }^{27}$ to a number of Amhara historical fictions narrating the dramatic events of Italy's 1935 1936 military aggression and continuing violence against Ethiopian civilians. In ways similar to other African postcolonial writers, who have addressed the question of historicity as a project of cultural identity-building beyond colonial historiographies ${ }^{28}$ I place Gharmandi's narrative within this consolidated tradition by the way in which it contributes to the bulk of Ethiopian historical 
fictions. Yet hers is an exceptional re-reading of these events. A number of works written in Amharic open with the Italian invasion as a formative incident, the event that shapes the subsequent development of the story. ${ }^{29} \mathrm{~A}$ drama, written in rhymed verse by Seneddu Gäbru, for instance, deals with the shocking episodes of Yekatit $12^{\text {th }}$, the massacre of Ethiopian civilians that followed the attempt on Marshal Graziani's life in 1936. The second scene of the drama opens on the day of the massacre.

The novel presents the action through the witness of a frightened young woman who watches the unfolding of the killings from a window. ${ }^{30}$ Similarly, Ghermandi narrates the dramatic events of Yekatit $12^{\text {th }}$ from the perspective of two young women who witness them from the secluded domestic space of a house in Addis Ababa. In Elyas Bäšah's story What Man Conceals, God Reveals, the leading female character leaves her husband for a man who has been collaborating with the Italians. The author punishes her for this sin. By the end of the novel, she ends up in prison, where she dies of typhus. ${ }^{31}$ In Regina di fiori e di perle, Amarech falls in love with an Italian soldier who deserts and moves on the side of the resistance fighters. Both are captured and killed. As a I have demonstrated elsewhere, this plot line is a postcolonial twist on Ennio Flaiano's notorious story in Tempo di uccidere. ${ }^{32}$ But there is more to it. As a cautionary tale, and similarly to its Amhara counterpart, the tragic ending reveals its moralistic intent. A fatal destiny awaits those who engage in intimate relationships with the enemy, especially in the context of the violent anti-miscegenation regime that Mussolini imposed in the Horn of Africa. Yet, in Ghermandi's version, a baby girl is born out of the encounter between the Ethiopian woman and the Italian man. The multiple genealogies inscribed within the life of this fictional Ethiopian Italian daughter signal Ghermandi's emancipation from the literary and ideological constraints of both Ethiopian patriotic 
literature and Italian colonial legacies. Her novel affirms a new filial descent that is neither exclusively paternal nor maternal. It is a twentieth-first century narrative that acknowledges colonial intimacies and re-reads the colonial legacy from a diasporic perspective, deviating from the univocal expression of nationalist literatures. This type of historicity runs counter of revisionist claims, illuminating the complexity of a gendered reclaiming of memory in the contested field of postcolonial remembering.

Somali Italian narratives show an equal degree of historical awareness. Cristina Ali Farah's Madre piccola spans over three key historical moments in contemporary Somalia: the crumbling of Siyad Barre's dictatorship, the ensuing civil war, and the on-going Somali diaspora. The novel employs a first-person narration in order to stage the voices of three protagonists, two women (the cousins Domenica Axad and Barni), and a man (Taageere). Each voice speaks to interlocutors who are, alternatively, intimate to the narration or external and extraneous to the Somali community. ${ }^{33}$ These external listeners are all Italians, a journalist, a cultural mediator, and a psychologist. They represent specimens of the institutional roles Italian mediators hold as the official voice of migrants in Italy. Ali Farah's multi-vocal text adopts multiple languages - English, Italian, Somali, and Somali calques of Italian words - to convey the complex layers of diasporic self-translations. Moreover, the title of the novel "Madre piccola" is a term (and a figure) translated from the Somali 'habaryar', referring to a maternal aunt. While its meaning has no equivalent in Italian, the term makes sense in order to portray the social and affective bond between Domenica Axad and Barni.

Ali Farah's creative manipulation of both Somali and Italian inscribes within its prose the indelible traces of Somali oral poetry. Somali's orality, for Ali Farah, is a way 'to recreate the rhythm, the sequential narrative, the sense of humor and the Somali way to tell stories'. ${ }^{34}$ The novel's very first line reproduces the dominant line of the Somali poem 'Soomaali baan ahay' 
(Somali, am I) written in 1977 by Cabdulqaadir Xirsi Siyaad, one of the most celebrated contemporary Somali poets. Ali Farah takes liberty stylistically with this specific Somali poetic source. The song-poem "Soomaali baan ahay" was written at the time of the expulsion of Russian troops from Somalia at the end of the war against Ethiopia over the contentious issue of the Ogaden border. It was a time of great international isolation, and the poem affirms and defends the independent spirit and traditional ideals of Somali identity. ${ }^{35}$ Ali Farah takes the liberty to change the order of the stanzas, inverting their syntactical structure. Her Italian version transgresses the constraints of self-translation by maintaining the reiterated ending line of each stanza ('soomaali baan ahay') in the Somali original.

Another example of creative reclaiming of the Somali oral tradition is the blending of the song "Xamar waa lagu xumeeyeyeey" (Lament for Mogadishu) in Taageere's monologues in the novel's interlude and finale. Authored and performed by poet and singer Axmed Naajii Sacad, the song, written in 1991-1992, is dedicated to Mogadishu in the brink of the civil war. Axmed Naajii is one of Somalia's most accomplished and versatile song-writers, a diasporic artist whose music became enormously popular among Somali fleeing the country. In 1991, certain political and military leaders in Somalia, wishing to gain exclusive control over the state, mobilized their followers to use terror-wounding, raping, and killing — to expel a vast number of Somalis from the capital city of Mogadishu, and south-central and southern Somalia. Manipulating clan sentiment, they succeeded in turning ordinary civilians against neighbors, friends, and coworkers. ${ }^{36}$ In the refrain of the song, Axmed Naaji presents Mogadishu as a woman who has been raped and unable to restore her honor. The figuration of the city as a woman has a strong a political meaning because it asserts bonds of kinship wider than those imposed by patrilineal, clan logic. ${ }^{37} \mathrm{In}$ denouncing the civilian violence unleashed among 'maternal relatives and in-laws, ${ }^{38}$ the song 
represents the rejection of paternal clan thinking in favor of a common statehood, a position shared by artists such as Axmed Naji and the generation that witnessed both the birth and collapse of the Somali state.

The experience of clan violence in Mogadishu at the beginning of the 1990s resonates in Ali Farah's Madre piccola through Taagere's voice, the only male diasporic figure. At the end of the Interlude, lines from Axmed Naaji's song enrich Taagere's monologue, addressed to Mogadishu: 'you are the place where my umbilical cord were buried,' 'we used to reside in you calmly, safely, and freely'. ${ }^{39}$ Most significantly, the image of Mogadishu as a defiled woman ('Xamar became like that. Like a woman whose skin clings to her bones' ${ }^{40}$ highlights the function of Axmed Naji's sub-text. The song sets the stage for one of the most important themes of the novel, that is, the reconciliation of filial multiple identities. The suturing of a filial laceration between paternal and maternal descents is indeed a dominant theme not only in Madre piccola, but also in Ali Farah's poetic work. Her 2006 poem Strappo (Tear) ${ }^{41}$ draws from the author's experience as a participant in a training session on the practice of female genital mutilation. In the context of the training session, the poet returns to a memory of adolescence: 'An adolescent with a flexible body/On the sand, amongst her peers,/I fall in a split./Careful not to tear!/You will spill blood. Ceeb.' ${ }^{42}$ As Ali Farah explains, this injunction to be careful stems from her girlfriends' assumption that she, like them, had been infibulated and therefore run the risk of a tear ('strappo'). Yet, as she explains in an interview, 'I did not have that problem, that is why I was so disinhibited. I had to explain that no, I had not been sutured, therefore I did not run any risk [...]. I did not feel excluded, but I felt I possessed something different that distinguished me: first of all, I was only half Somali'. ${ }^{43}$ Ali Farah also adds that for many Somali women, female genital mutilation is 'a recognizable sign of belonging, an esthetic sign of beauty and purity'. ${ }^{44}$ The distinction of being 
'only half Somali' is rendered poetically as a filial laceration between belonging to both maternal and paternal descent, a theme that marks much of Ali Farah's early work. In this sense, the author poses the question of Somali Italian diasporic identity not as an assimilationist desire for Italianness but, on the contrary, as a sense of aspiration to and alienation from Somaliness.

The double filial nexus is evident in Ali Farah's use of Italian and Somali. As Ali Farah notes, 'rendering familiar an extraneous term means, metaphorically, the suturing of a laceration, and this is absolutely coherent with my poetic work'. ${ }^{45}$ The poem conjures the suturing of the laceration through a poetic device that visually and metonymically associates Somali and Italian. The last line of the second stanza: 'You will spill blood. Ceeb' ('Goccerai sangue. Ceeb') exploits the visual closeness in the transliteration (not in the phonetic pronunciation) of the Somali 'ceeb' (shame) and the Italian 'goccerai' (spill) (emphasis mine) in order to align visual signs of the two languages. The couple ceeb/goccerai simultaneously works within the 'strappo' of the semantic couple shame/spill in a complex yet coherent way. In the eye of her Somali cohorts, the flexible body of the young girl may bleed because of the assumption that she, too, was cut. Yet, conscious of her lack of a presumptive genital wound, she feels shame. Similarly, in the following stanza, 'I will never find a husband. I am not pure, sealed, beautiful. Those little hanging labia/they are ugly. Caado'. ${ }^{46}$ the Somali word 'caado' visually resembles the Italian 'cado' (I fall), while also referring back to bleeding, as one of the possible meanings in Somali of the term caado is menstruation. An alternative meaning is custom, another possible reference to infibulation. The insertion of the Somali word 'caado' refers back to 'goccerai sangue', as a foreshadowing of female adulthood, as well as bleeding for tearing as a consequence of genital cutting. Yet, in this particular line, it also evokes the shame of a corporeal, genital aesthetics of impurity ('Those little hanging labia/they are ugly'). If for Somali women female genital cutting is a mark of aesthetic beauty and univocal 
national belonging, the Somali Italian author of the poem Strappo marks her distinction with a poetics of impurity that mixes sign and meaning, signifier and signified, in order to simultaneously create a metonymic continuity of Somali with Italian and a metaphorical disjunction of multiple affective, filial bonds.

In Madre piccola, the Somali language and its poetic legacy anchor the novel within a Somali cultural lineage but also creatively deviates from its literary constraints. The aesthetic principle and expressive potential of Somali poetry and orality reflect the formative role that poetry and orality have had, more generally, on the narrative forms of the African novel. In this sense, the use of the Somali language as a medium of literary expression, while central to the emergency of contemporary African literature, also offers a context for 'a discourse of dissidence' within the Somali political culture in exile. ${ }^{47}$ In particular, as the novel explores the polyvocal dispersal of the Somali diaspora across time and space, Ali Farah's use of the Somali national language represents a conscious political call for unity in the face of the twenty years of bloodshed among fractured clan genealogies. Yet its presence in Ali Farah's narrative in Italian also serves a more intimate and private goal, that is, establishing a way of belonging to both the paternal and maternal descent. For Domenica, one of the three internal voices of the narrative and the most autobiographical, the search for the Somali paternal roots passes through the Somali language but also implies a carnal incision, a painful separation from the Italian mother and tongue.

At the end of Domenica's narrative, we learn that she has given birth to a son, named Ta'rikh, the word used to refer to the Arabic written chronicles that have for long been the source of African regional history. Ta'rikh was circumcised in order to belong to the paternal Somali descent. Yet he is learning Italian because it is, after all, his mother's mother tongue. The Italian language, like the incision on Ta'rikh's infant body, is a scar inscribed in the body of the text, 
marking the creation of Ali Farah's novel in a new filial tongue, neither solely Italian, nor solely Somali. Ta'rikh' reclaims a double lineage through language and circumcision; similarly, Ali Farah reclaims a double lineage through a post-national and diasporic aesthetics of laceration and impurity.

In their unique blending of oral and written sources, Ghermandi and Ali Farah affirm their cultural and textual autonomy from both the African literary tradition and Italian "migrant" writing. As part of a larger body of diasporic African expression, their work calls into existence the dilemmas and cultural discourse of diasporic, postcolonial voices. Ghermandi's latest foray in the music industry, blending storytelling, music, and words, represents 'a new, transitory, and "discursive" Ethiopia, generated between the new Horn of Africa and the new Italy'. ${ }^{48}$ As she explained when asked about the her work's affiliation, Ali Farah's creative and scholarly commitment to Somali culture through her work for the Somali Archive and Somali Study Center at the University of Roma Tre, her doctoral thesis on the Somali folk theater, her collaboration with Archivio Migrante and Asinitas in collecting oral stories of Somali women, and her inspiration from African writers such as Wole Soyinka, Mia Couto, Zoe Wicomb, Bessie Head, Ousmane Sembene, Nuruddin Farah, Toni Morrison, and Chinua Achebe, all attest to the deep African roots of her trajectory. ${ }^{49}$ The language and cultural references Ali Farah and Ghermandi conjure and reinvent are the expression of a new generation of African Italian women's artists who, through diaspora and double descent, have moved away from the territorial univocality of both European and African national traditions by remaining anchored to a larger, more inclusive, black diasporic world. 
${ }^{1}$ Originally published in Italian, both novels were translated into English as part of the prestigious series Global African Voice, edited by Dominic Thomas for Indiana University Press. Significantly, both entered the Anglophone editorial market as ‘African' novels. See: Cristina Ubax Ali Farah, Little Mother. A Novel, translated by Giovanna Bellesia-Contuzzi and Victoria Offredi Poletto (Bloomington and Indiana, Indiana University Press, 2011), and Gabriella Ghermandi, Queen of Flowers and Pearls, translated by Giovanna Bellesia-Contuzzi and Victoria Offredi Poletto (Bloomington and Indianapolis: Indiana University Press, 2015). For the original version see: Cristina Ubax Ali Farah, Madre piccola, (Milan: Sperling \& Kapfer, 2007), and Gabriella Ghermandi, Regina di fiori e di perle, (Roma: Donzelli Editore, 2007).

${ }^{2}$ The project, fully independent and self-financed, started in 2010 in Addis Ababa, as a result of a collaboration among Gabriella Ghermandi, the Ethiopian composer Aklilu Zewdy and Professor Berhanu Gezaw. It immediately caught the interest of Michele Giuliani, an Italian pianist and composer who is the leader of the Reunion Platz Jazz Trio. The intended scope of this joint venture is to bring back to their traditional resistance war songs 
to Ethiopian patriots. For further details see https://www.worldmusic.net/battle/track/gabriella-ghermandi-atse-tewodros-from-atse-tewodros-project/. For further details see: Laura Dolp and Eveljn Ferraro, 'Songs of Passage and Sacrifice: Gabriella Ghermandi's Stories in Performance,' in Artistic Citizenship: Artistry, Social Responsibility, and Ethical Praxis, ed. by David J. Elliott, Marissa Silverman, and Wayne Bowman (Oxford, UK: Oxford University Press, 2016), pp. 415-45.

${ }^{3}$ George Olakundle defines the oral-literate dyad as a site of "deep existential investment for African people", and invites critics to pay higher attention to it as "an analytical category in literary studies". George Olakundle, 'The oral-literature interface', in The Cambridge Companion to the African Novel, ed. by F. Abiola Irele (Cambridge, UK: Cambridge University Press, 2009) pp 15-30 (p. 15). For an analysis of orature and the African inspiration of Ali Farah's and Ghermandi's work see: Daniele Comberiati, ed, La quarta sponda. Scrittrici in viaggio dall'Africa coloniale all 'Italia di oggi (Rome: Edizioni Pigreco, 2007); Simone Brioni, The Somali Within: Language, Race and Belonging in 'Minor' Italian Literature (New York: Legenda, 2015); Maria Grazia Negro, Il mondo, il grido, la parola. La questione linguistica nella letteratura postcoloniale (Firenze: Franco Cesati Editore, 2015).

${ }^{4}$ Keith M. Booker, 'The African Historical Novel,' in The Cambridge Companion to the African Novel, ed. by F. Abiola Irele (Cambridge, UK: Cambridge University Press, 2009), pp. 141-58 (p. 141).

${ }^{5}$ Alessandra Di Maio, 'Postcolonial Intersection: Transnational Women Voices from Minor Italy', InVerbis, 1 (January-June, 2017), pp. 101-22 (p. 111).

${ }^{6}$ Loredana Polezzi, 'Polylingual Writing and the Politics of Language in Today's Italy', in New Perspectives in Italian Cultural Studies: Definition, Theory, and Accented Practices, ed. by Graziella Parati (Madison and Teaneck: Fairleigh Dickinson University Press, 2012), pp. 72-86 (p. 82).

${ }^{7}$ Lucia Quaquarelli, 'Decentrare la lingua. Alcune considerazioni sul caso italiano', in Cosmo: Comparative Studies in Modernism, 11 (Fall 2017), pp. 73-84 (p. 81).

${ }^{8}$ Ibid., p. 78.

${ }^{9}$ Polezzi, ‘Polylingual Writing and the Politics of Language in Today’s Italy’, p. 75.

${ }^{10}$ Ibid., p. 82.

${ }^{11}$ Brioni, The Somali Within.

${ }^{12}$ Ibid., p. 27.

${ }^{13}$ Di Maio, 'Postcolonial Intersection", XIX.

${ }^{14}$ Brioni, The Somali Within, p. 48.

${ }^{15}$ Personal communication with the author, March 22, 2009.

${ }^{16}$ Personal communication with the author, March 22, 2009.

17 As the editor of the Italian version of Regina di fiori e di perle, I became aware of the contentious nature of this particular editorial choice in the course of the relationship between Ghermandi and the Italian publisher Donzelli. 
One of my roles was indeed to ensure that the novel would not be encumbered by excessive use of paratextual footnotes and glossary.

18 Abrham Demoz, 'State Policy and the Medium of Expression', in Silence is not Golden: A Critical Anthology of Ethiopian Literature, ed. by Taddesse Adera and Ali Jimale Ahmed, (Lawrenceville, NJ: The Red Press Sea), pp. 15-38.

${ }^{19}$ Ibid.

${ }^{20}$ Solomon Deressa, 'Poem and Its Matrix', in Silence is not Golden: A Critical Anthology of Ethiopian Literature, ed. by Taddesse Adera and Ali Jimale Ahmed (Lawrenceville, NJ: The Red Press Sea, 1995), pp. 169-81 (p. 171).

${ }^{21}$ Taddesse Adera and Ali Jimale Ahmed, eds, The Road Less Traveled: Reflections on the Literatures of the Horn of Africa. (Lawrenceville, NJ: The Red Press Sea, 2008).

${ }^{22}$ Ali Moussa Iye, 'Reflections on the Literatures of the Horn of Africa: The Case of Somali Literature,' in The Road Less Traveled: Reflections on the Literatures of the Horn of Africa, ed. by Taddesse Adera and Ali Jimale Ahmed, (Lawrenceville, NJ: The Red Press Sea, 2008), pp. 81-92, (p. 83).

${ }^{23}$ Di Maio, 'Postcolonial Intersection”, XVIII.

${ }^{24}$ Ghermandi, Queen of Flowers and Pearls, p. 247.

${ }^{25}$ Ibid., p. 6.

${ }^{26}$ Ibid., p. 253.

${ }^{27}$ Ghermandi has not acknowledged any written texts as source of inspiration for her novel. Personal communication with the author, July 15, 2019. It is possible to speculate, however, that some of people she interviewed during her travels might have been exposed to written texts recounting the events narrated in the novel.

${ }^{28}$ For an illustration of this process more generally see Booker, 'The African Historical Novel'.

${ }^{29}$ Thomas Leiper Kane, Ethiopian Literature in Amharic (Wiesbaden: Otto Harrassowitz, 1975) pp. 151 -152.

${ }^{30}$ Excerpts of the fiction in English translation are found in Kane, Ethiopian Literature in Amharic, p. 156.

${ }^{31}$ Kane, Ethiopian Literature in Amharic, p. 152.

${ }^{32}$ See: Cristina Lombardi-Diop, 'Postfazione,' in Gabriella Ghermandi, Regina di fiori e di perle (Rome: Donzelli Editore, 2007), pp. 255-264.

${ }^{33}$ For an explanation of the construction of the novel's structure see Cristina Ubax Ali Farah, Interview with Daniele Comberiati. http://www.retididedalus.it/Archivi/2007/maggio/METICCIA/comberiati.htm.

${ }^{34}$ Daniele Comberiati, ed., La quarta sponda, p. 46. 
${ }^{35}$ Francesco Antinucci and Axmed Faarax Cali Idaajaa, eds., Poesia orale somala: storia di una nazione. Studi somali 7, (Roma: Ministero degli AFFARI Esteri, 1986).

${ }^{36}$ Lidwien Kapteijns, Clan Cleansing in Somalia: The Ruinous Legacy of 1991, (Philadelphia: University of Pennsylvania Press, 2012).

${ }^{37}$ Ibid.

${ }^{38}$ Kapteijns, Clan Cleansing in Somalia, p. 29. A transcription of the poem appears in Kapteijns, pp. 28-9.

${ }^{39}$ Ali Farah, Little Mother, p. 127.

${ }^{40}$ Ibid., p. 126.

${ }^{41}$ Originally published in Ai confini del verso. Poesia della migrazione in italiano, ed. by Mia Lecomte (Florence: Le lettere, 2006), pp. 30-31.

42 'Un'adolescente snodata/Sulla sabbia, in mezzo alle coetanee,/cado giù in spaccata./Attenta che ti strappi!/Goccerai sangue. Ceeb'. English translation is mine. In Comberiati ed., La quarta sponda, p. 49.

43 'Io non avevo quel problema, per questo ero cosí disinvolta. Dovevo spiegare che no, io non ero cucita quindi non correvo pericolo. [... Io non mi sentivo esclusa, ma sentivo di avere qualcosa di diverso che mi distingueva: innanzitutto ero somala solo per metà'. English translation is mine. In Comberiati, ed., La quarta sponda, p. 51.

44 'un segno riconoscibile di appartenenza, un segno anche estetico di purezza e bellezza'. English translation is mine. In Comberiati, ed., La quarta sponda, p. 51.

45 'rendere familiare un termine estraneo significa, metaforicamente, ricomporre la lacerazione e questo è assolutamente coerente con la mia poesia'. English translation is mine. In Comberiati, ed., La quarta sponda, p. 50.

46 'Non trovero' marito./Non sono pura, chiusa, bella./Quelle piccole labbra pendenti,/sono brutte. Caado.' English translation is mine. In Comberiati, ed., La quarta sponda, p. 50.

${ }^{47}$ Abiola Irele, 'Introduction: Perspectives on the African Novel', in The Cambridge Companion to the African Novel, (Cambridge, UK: Cambridge University Press, 2009) pp. 1-14 (p. 10).

${ }^{48}$ Dolp and Ferraro, 'Songs of Passage and Sacrifice,' p. 435.

${ }^{49}$ Personal communication with the author, October 23, 2018. 
